\title{
Notes on Samuel Hearne's Journey from a Bibliographical Perspective
}

\author{
I. S. MacLaren ${ }^{\dagger}$
}

I

Samuel Hearne's Journey from Prince of Wales's Fort (1795) has as its climax - in terms of drama and nearly in terms of the explorer's geographical surveys - the notorious scene of the massacre on 17 July I77I of Inuit by Chipewyan and Copper Indians eight miles upstream from the mouth of the Coppermine River. ${ }^{\mathrm{I}}$ This scene has been excerpted in various forms and critically interpreted more often than any other section of this classic of North-American exploration. The source for these excerpts and interpretations has been either the first edition or one prepared in 1958 by the historian Richard Glover. ${ }^{2}$ With respect to the massacre, these editions contain an element - torture - that one cannot find in the two surviving versions of Hearne's field notes. One of these versions is 'Mr. Hearne's Narrative,' which is known to date from I79I, and which is held by the Department of Manuscripts, British Library; ${ }^{3}$ a transcription of it is at the National Archives of Canada. ${ }^{4}$ The other version is entitled 'Hearne's Journal $1770-72$ from the Original in the Possession of the Hudson's Bay Company.' This is also held by the Department of Manuscripts, British Library. ${ }^{5}$

Some of the incidents of torture begin to emerge in what appears to be the second-stage version of the event, a journal probably written upon Hearne's return to Fort Prince of Wales (Churchill) in I772. The extant fragment of the journal (assuming that an entire journal was written/ comprises the massacre scene, almost to the exclusion of every other portion of the narrative. Like the field notes, it has not survived in Hearne's hand; it appears in fellow fur-trade factor Andrew Graham's miscellany, a version of which was published for the first time in $1969 .{ }^{6}$ But this is a retrospective journal; even if it were extant in Hearne's hand, the preponderance in it of

+ I.S. MacLaren is a member of the Department of English at the University of Alberta, where he also teaches in the Program in Canadian Studies. 
the past tense makes clear that it was not written while Hearne sojourned. Furthermore, uncertain bibliographical details about Graham's own manuscripts leaves open the possibility that the fragment, far from being set down immediately upon Hearne's return to Fort Prince of Wales in I772, might have been written as late as twenty years later. Meanwhile, in the field notes kept by Hearne during the more than two years that he spent walking from Hudson Bay to Coronation Gulf at the northern edge of the continent, torture is not present; on the contrary, the Inuit are massacred in their sleep.

Knowing that the torture came later, as the field notes evolved into a journal and then into a book, may help to throw into relief the motivation behind the regularity with which historians, poets, ${ }^{7}$ anthologists, and critics focus on the massacre. Onward from I 823, when the scene seems, apart from reviews of the first edition, to have been printed on its own for the first time, ${ }^{8}$ a certain fascination has held at least white readers in thrall. Meanwhile, Peter C. Newman's pulp history of the Hudson's Bay Company, Don Gutteridge's less well known but gratuitously obscene verse rendition, and anthologies of Canadian literature used in university classrooms have kept modern Canadian readers' attention rivetted on the torture. Of course, excerpts necessarily provide a different context for an original passage, and, usually, result in the passage serving as a synecdoche of the work as a whole, especially if the remainder of the narrative is not read. In the most altered of all the excerpts, not even the original work is mentioned; the case is Miss Coleson's Narrative of her Captivity among the Sioux Indians! (I864), whose author lifted the massacre scene from the Journey and transplanted it to Rainy River, on the Ontario/Minnesota border, where German settlers are virtually identically victimized by Sioux, but in the dead of winter. ${ }^{9}$

From a textual perspective, one might defend this pattern of republication by advancing the argument that, neither version of the field notes nor the journal having survived in Hearne's own hand, they are unreliable and cannot be quoted. It seems that one can do no more than remark editorially, as Glover did when only the Stowe ms of the field notes was known, that the one retrospective sentence in the first edition's version/'even at this hour I cannot reflect on the transactions of that horrid day without shedding tears') makes 'evident ... [that] the foregoing passage [the entire massacre scene, one infers] is an addition to Hearne's original journal; so is the next paragraph. ${ }^{\prime 10}$ However, this possible, if 
extreme, bibliographical argument against the reliability of manuscripts that are not autograph manuscripts has not been advanced. Instead, scholars continue to rely on the published versions (the first edition or Glover's) but their practice is not the consequence of bibliographical decisions. As well as any, recent discussions of Hearne's explorations by historians, anthropologists, and literary critics and theorists rely unquestioningly on the source nearest to hand, as if it were a document. ${ }^{\text {II }}$

Both surviving versions of the field note for 17 July 1771 state unequivocally that the plan all along was to kill 'every soul' 'while asleep. ${ }^{\prime 2}$ By repetition the field note confirms that the plan was realized; that is, the massacre 'was soon accomplished, the inhabitants being all asleep': ${ }^{3}$ ' . . . the Indians crept under some of the rocks within 100 yards of the tents where they lay some time to watch the motions of the Esquimaux but finding all asleep as they supposed by seeing nobody stir without they ran on the tent on a sudden $\&$ killed every soul before they had power to rise in the whole 21 persons. ${ }^{\prime 4}$ Only in the next stage of the narrative - the retrospective journal - does torture begin to appear. This version features the first appearance of the remarkable girl who appeals to Hearne for her life by twisting round his legs. ${ }^{15}$

The field note differs from the published account in another respect. It adduces a further motive for the decision to have Hearne accompany the warriors rather than remain 'behind the Cliff.' The 'Captain' (the name Matonabbee does not appear in either version of the field notes) clearly is concerned for Hearne's safety, but less out of any deep friendship than out of an astute concern that, were Hearne not returned safely to the Bay, the consequences for Chipewyans trading with the Hudson's Bay Company might be dire: 'At first my Capt ${ }^{\mathrm{n}}$ was very unwilling to consent [to Hearne's advancing with the warriors] saying a random arrow or many things might wound or kill me, $\&$ if so he never expected forgiveness from the English. ${ }^{16}$ But Matonabbee is of two minds about where Hearne will be safer: behind the cliff and well away from the action, where he might be vulnerable were one or more of the intended victims to escape and find him alone; or with the attackers. In the end, according to the note, the captain decides on the latter.

In many respects, Glover's edition of Hearne's narrative has worn well during its thirty-five years of existence, but it is also clear that Glover, because he held Hearne in high esteem or for other reasons, spent less bibliographical attention on the Stowe Ms than might have been spent by scholars with different interests and orientations 
to the text. Or, it may be that Glover decided, the Stowe ms not being in Hearne's hand, that the published stage of the narrative was the authoritative one; however, because Glover's introduction leaves no doubt that he considered Hearne the author of $A$ Journey, it is unlikely that he would have regarded such a decision as necessary. ${ }^{17}$ Nor does a fellow historian disagree with him. ${ }^{18}$ Just as certainly, however, researchers in each discipline that makes use of this purple patch and climax of Hearne's posthumously published book need to assess all the sources for themselves, especially because Glover's blunt editorial note for much of the massacre passage is, to put it equally bluntly, opaque. In any case, right from the start of $A$ Journey, the reader must regard with circumspection the author's hope that his 'humble Endeavours to relate, in a plain and unadorned Style, the various Circumstances and Remarks which occurred during that Journey, will meet with' the approbation of the company's governor, deputy governor, and committee. ${ }^{19}$

At the close of the eighteenth century, the gothic novel enjoyed its apogee of popularity in Britain. Elsewhere and relying on only one version of the field notes, I have argued for the possibility that contemporary narratives of exploration took on some of the colouring of that fictional genre just as, under Gutteridge and Newman's Stephen-King-like pens, the massacre's horror is heightened for popular consumption today. ${ }^{20}$ Without mentioning the most famous example, that of Christopher Columbus, ${ }^{21}$ M.J. Brand is helpful in noting that ' $t$ the practice of adding material to journals prior to publication was not uncommon' ${ }_{j}{ }^{22}$ nor, however, did the traveller/explorer always do the adding, the taking away, or the editing. The metamorphosis of explorers and travellers into published authors makes for intriguing study, and nowhere more than in cases where the explorers died before their books appeared.

Another case of posthumous publication, the famous one of Captain Cook's last voyage, is pertinent here because the John Douglas whom Glover discounts as Hearne's editor ${ }^{23}$ was known to have prepared Cook's last journals for publication. ${ }^{24}$ More than this, Douglas used the occasion of the introduction to those journals (prepared in the first-person singular, as if they were unchanged from Cook's wording) to call for the publication of Hearne's journal, a portion of which he quotes. ${ }^{25}$ From that portion, which does not match the same passage in either the Stowe Ms, the Grenville ms, or the published Journey, ${ }^{26}$ one infers the possibility of there having been several stages through which Hearne's narrative passed during

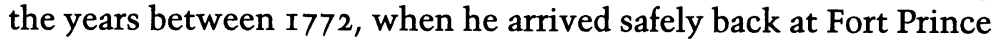


of Wales, and the first day of 1795 , just over two years after his death in November 1792, when the narrative appeared as a book. What one must then contend with is whether or not the alterations from one stage to the next are substantive from the perspective of one's particular discipline. That the published book alone presents Hearne in the literary fashion of the day as a sentimental traveller - even at this hour I cannot reflect on the transactions of that horrid day without shedding tears' $-{ }^{27}$ holds a certain interest; but for which disciplines is it a substantive interest? Moreover, what matter is it that only the published Hearne, when he reached the mouth of the Coppermine River the next day, 'took possession of the coast, on behalf of the Hudson's Bay Company,' or that only the publication names the site of the massacre 'Bloody Fall' ${ }^{28}$ New ground cannot be broken on this topic without more bibliographical attention being paid to this engrossing omnibus narrative. Following Glover is helpful only to a point, and one does not out-distance that point without extending one's search beyond Glover's thirty-five-year-old exertions. Now that doubt, albeit circumstantial doubt, has been thrown on Hearne's even being near the scene of the massacre, ${ }^{29}$ one can heartily endorse in the case of Hearne what Glyndwr Williams has suggested of other fur trade explorers' writings: 'It is one of the ironies of the history of the Canadian West that the journals of some of its most significant explorers - Radisson, Kelsey, La France, Pond - present ineluctable problems of reliability and even authenticity. ${ }^{\prime 30}$

\section{I}

Another concern relates to an unquestioned dependence on Glover's edition. Even within the published account there is a difficulty, one that bears on the not inconsiderable literature in Canadian journals concerning the line of Hearne's route to and from the Arctic Ocean. As Sean Peake has noticed, in at least one important case the wording of the first edition does not match that of most other editions. ${ }^{3 \mathrm{I}}$ Further scrutiny yields the concern that someone other than Hearne, by then deceased of course, noted on the errata page of the first edition that on 8 September I $77 \mathrm{I}$ during his return trip, the explorer walked, not 'North West, by the side of Point Lake, ${ }^{\prime 32}$ but 'South West, by the side of Point Lake.' 33 This change effectively takes Hearne home by a new route. Indeed, and to emphasize this discrepancy, page 202 in all of the eighty-three copies examined of 
the first edition printed for A. Strahan and T. Cadell (lvi $+458 \mathrm{pp}$., quarto) has Hearne's party shaping its 'course to the North West, by the side of Point Lake.' Moreover, only this direction, 'North West,' is consistent with the text of the field notes, which gives ' 17 or 18 miles to the West \& North by the side of Point Lake,' 34 and 'I 7 or I 8 miles to the W. \& N. by the side of point Lake. ${ }^{35}$ However, on the unnumbered verso of leaf $B_{4}$, that is, on page $[\mathrm{xx}]$, all the copies examined also bear a list of errata, the first of which reads as follows: '202 - I, for North West read South West.' The fact that the errata, which are not tipped in or inserted on a new sheet, are printed on a blank page in the original gathering suggests that the printing had begun before any errata, including the apparent error in Hearne's route on 8 September, were spotted and listed on a conveniently blank page between the Contents and the Introduction. ${ }^{36}$

Also in the first edition, the word 'North' is the catchword at the bottom of page 20I. Thus, in these eighty-three copies, 'North' appears on a line of its own at the bottom of page 201 and as the first word on page 202. Following the directions of the errata, eight of the eighty-three copies of the first edition that have been examined are 'corrected' in manuscript. For example, in the National Library of Canada's copy, which was filmed in 1982 as part of the Canadian Institute for Historical Microreproductions (Сінм) series, and is available in microfiches in most Canadian university libraries, 'North' appears as both the catchword of page $20 \mathrm{I}$ and the first word of page 202, but on the latter it is struck out by hand, and 'South' is written above it in pencil. ${ }^{37}$ (In only one of all the copies examined, the one held by Lehigh University, the catchword on page 20I is also thus corrected.) At the risk of stating the obvious, then, this evidence, in tandem with the evidence of the Stowe and Grenville Mss, has the clear virtue of confirming beyond any doubt the order of the change of direction, from the typeset North West, to the handwritten 'correction,' South West. No copies of the first edition have as yet surfaced without the errata page or with the actual type changed to 'South' in either the catchword on page $20 \mathrm{I}$ or the first word on page $202 .{ }^{38}$

In the first decade of this century, when J.B. Tyrrell prepared his 'new edition' 39 for the Champlain Society, which also correctly indicates the first edition's page breaks by means of bracketed numbers, he apparently corrected the errata himself, for his edition reads 'South West ${ }^{\prime{ }^{\circ}}$ and the other four errata ${ }^{4 \mathrm{I}}$ are also corrected. The word 'apparently' is necessary, however, and for two reasons. First, despite following the page breaks of the London edition of 
1795, Tyrrell could have been working not from that edition but from the Dublin edition, an octavo, of a year later the page breaks of which are different, and in which the errata are all corrected. Second, Tyrrell does not alert his reader to the changes he made, and does not include the errata page from the first edition. Almost needless to say (see below), the facsimile edition made from Tyrrell's is identical. ${ }^{22}$

By mid-century, Glover, who does not inform his reader which edition he chose for the copy-text of his own, has Hearne walking 'South West. ${ }^{\prime 43} \mathrm{He}$ also made the other four 'corrections' following the first edition's list of errata. ${ }^{44}$ Was Glover's copy-text the text of the second edition, the one printed in Dublin in 1796? In all copies of that edition inspected, 'South West' appears as the direction. ${ }^{45}$ As he states, Glover did choose to print the inferior plates from that octavo Dublin edition..$^{46}$ On the other hand, without stating as much, he also used the inferior map (Fig. 2) from that edition, ${ }^{47}$ the one that departs from the map in the first edition (Fig. I) in several respects, including a misspelling of the Arctic Circle as 'Artic,' and the lack of the name, 'Point Lake.' Yet Glover permits his reader to infer that the first, the London quarto, edition served as his copytext because he provides a facsimile of what he calls the "Title Page of the First Edition' (Fig. 3) $1{ }^{48}$ Even so, this facsimile raises problems of its own, for it diverges in several respects from the title-page in copies of the first edition inspected for the present occasion (Fig. 4). The word JOURNEY is printed in italics in the first edition's title-page, but not in Glover's facsimile; the ' $s$ ' in the HUDSON's of 'HUDSON's BAY COMPANY' (not of HUDSON'S BAY) is in the lower case; and the punctuation following COMPANY is a comma, whereas in Glover's facsimile the ' $s$ ' is in upper case and the punctuation is a period. Also with respect to punctuation, Glover's facsimile introduces a comma after 'Fort' where none appeared in the first edition. Finally, the last line has a period after the date of 1795; Glover's facsimile does not. Neither, however, does Glover's facsimile reproduce the title-page of the second, the Dublin edition. The title-page in 1796 (Fig. 5) differed from that in 1795 in some of the ways that Glover's facsimile does - that is, the JOURNEY in roman, a comma after 'Fort,' a period rather than a comma following COMPANY, and an upper case ' $S$ ' in HUDSON'S; but Glover's facsimile, like the first edition alone, prints 'Prince of Wales's Fort, in Hudson's Bay,' on one line, while the narrower octavo edition uses two lines, the second of which is in upper case italics.

While Tyrrell's, Glover's, and the second edition provide 'South 
West' as Hearne's route, other editions do not agree. In I798, Dutch and Swedish translations appeared. According to the copies of these translations made in 1982 for CIHM, Dutch readers encountered Hearne walking south west, 'zuidwesten'; 49 Swedish readers, however, found him ranging north west, 'Nordwast, ${ }^{50}$ and he was still headed in that direction a year later when met by French readers 'Nord-Ouest. ${ }^{\prime 5 I}$ In fact, as late as four years later, when the American abridgement appeared, Hearne was headed 'north west. ${ }^{\prime 2}$ But the most original resolution was offered in the first translation, published in German in 1797 and with notes, a year before his death, by Johann Reinhold Forster, whose work would produce the Dutch translation the next year. In the German translation, Hearne does not set off in one or the other direction towards Point Lake; he simply goes farther: '. . . und am folgenden Morgen gingen wir weiter.' 53 Whether or not Forster, the distinguished scholar and naturalist aboard Cook's second voyage to the Pacific, observed that the London and Dublin editions disagreed and consulted the translator on the matter (if he did not himself serve in that capacity) is uncertain; what is certain is that a recent German translation, and the most recent edition in any language, faithfully follows Forster farther: '. . . und am folgenden Tag gingen wir weiter. ${ }^{\prime 54}$

German inventiveness, however, appears to have been matched in a very popular facsimile reprint of the first edition, known widely as the Hurtig reprint. 55 This was, however, not the first facsimile reprint of the first edition. That was the $\mathrm{Da}$ Capo facsimile, which was published in $1968 .{ }^{.6} \mathrm{In}$ it, all the signatures appear as they are in the copies of the first edition examined. Also in it, Hearne's direction on 8 September $177 \mathrm{I}$ is 'North West' at page 202, and the list of errata appears where one expects it, on the verso of leaf $B_{4}$. On the other hand, the Hurtig facsimile reprint, made three years later, is not identical. Like Da Capo's facsimile, it is a photographic, not a typographic (i.e. re-typeset), facsimile. It too has ' $N o r t h$ ' as the catchword on page 20I, but 'South' (i.e. 'South West, by the side of Point Lake') as the first word of page 202, a confusion perhaps suitably metonymic of Hearne's trek but hardly enlightening. The copy from which the facsimile was made has not been located and perhaps it does not exist. Mr. Hurtig remembers clearly that his own personal copy was used for the making of the facsimile reprint, but his, by agreeing with all other copies of the first edition that have been examined, disagrees with the facsimile reprint in respect of 'North West.' 57 As well, his copy possesses both the page of errata and signatures at the bottom of pages, neither of which appear in 
the Hurtig facsimile. The Canadian edition also has printed corrections of the other four errata listed on the first edition's errata page, and perhaps this explains why it does not reprint the errata page itself. (Why it nowhere includes the map of Hearne's route, which is positioned facing the title page in the first edition and in the first facsimile reprint, is another question.) In order to accommodate L.H. Neatby's new introduction, one further change was introduced into this facsimile reprint (suddenly, a loaded term): all pages with roman numerals have been renumbered in a modern Bembo type similar but not identical to that of the first edition. Indeed, because the word 'South' seems slightly on an angle to the rest of the first line of page 202 and because no copy of the first edition has yet surfaced which bears the change to 'South' in the type itself, one must infer, at least until further evidence surfaces, that Hurtig's printer (Charles E. Tuttle Company, of Rutland, Vermont) used type that matched the Bembo type in which the first edition was set, and incorporated into Hurtig's facsimile reprint the changes on the errata page of the first edition. This amounts only to unconfirmable speculation, for correspondence with the Tuttle firm has yielded no editorial file for this work, Tuttle no longer employs anyone who worked with the firm when the facsimile reprint was made, and Charles Tuttle himself, the president at the time, is prevented by illness from looking further into the question. ${ }^{58}$

In the absence of supporting evidence, the usual test of diagonal linear collation was made, setting a straight rule diagonally across the same page (202) in various copies of the first edition in order to discover if the line passes through the same letters at the same points. In this particular case, the rule was set twice, from the first word and, because it is the questionable one, from the second word down to the left edge of the last letter in the last row. The results indicate nothing definitive, for although there is a slight discrepancy between the line in the Hurtig reprint's 'South' and the line in other copies of the first edition, there are also slight discrepancies among those copies themselves - no surprise given the common occurrence of type shifting.

Regrettably, neither has any written information survived in the files of Hurtig Publishers concerning the copy used for the Hurtig facsimile reprint. This leaves one in the perplexity of an unsatisfactorily tentative conclusion: in the case of the 8 September I77I portion of Hearne's route, the Hurtig facsimile reprint is not a facsimile reprint of the first quarto edition. It may be that eightythree copies, randomly acquired and located at present across a wide 
geographical spectrum, do not suffice to cover all the variants in the impression of the first edition, in which case room must be left to accommodate the possibility that, if the press was stopped and the errata corrected, a copy exists of the first edition with the words 'South West' printed. However, it remains the case that the errata could not have been listed by the deceased Hearne, and that the specific erratum concerning Hearne's route disagrees with the contents of the two known surviving copies of his field notes.

The facsimile reprint by Hurtig, part of his mammoth and welcome Canadiana Reprint Series of the late 1960s and early I970s, seems to have been produced by photography, but that process does not exclude the possibility of alteration to the text. This may occur intentionally, as in replacing words here and there in order to correct errata. It may also occur accidentally. Although all copies will have been printed from the same type, they will vary from one another in press work or in inking of the type. Visually less attractive if not actually illegible, the print on several pages of one copy might not pass muster before the modern reprint publisher, who will decide to switch to another copy of the same edition for a portion of the photographing. Thus does the facsimile become a photographically composite reprint, which may not resemble in every respect any single copy of the original. When the aim of a reprint series is chiefly to make available to the reading public old and rare works, the visual appearance of a page might understandably concern the publisher more than matters bibliographical. As is well known, the process of composite photography was practised by no less a name in reprint publishing than The Scolar Press, which, by switching to other copies of a work during the photographing, innocently created entirely new editions precisely when it thought it was furnishing new copies of first editions.

Tyrrell's and Glover's are scholarly editions, however; scholars like themselves have grown to depend on those editions, although they alone must answer for not going back to the sources, where they are extant, to see matters for themselves, instead of assuming that the most recent edition is the best one. The contradiction in Hearne's route will seem a minor one to many but not to those who have spent a deal of time trying to determine Hearne's route to and from the Arctic Ocean. This list includes, perhaps most agonizingly, John Franklin, John Richardson, Robert Hood, and George Back during the first of Franklin's two overland expeditions. ${ }^{59}$ In this century, Tyrrell, Charles Camsell, Guy Blanchet, J. Tuzo Wilson, William Fuller, Eric Morse, and Sean Peake all have sought the 
definitive interpretation. ${ }^{60}$ Nor can one overlook these writers' interested readers. It would be facetious to align the notorious problems of Hearne's longitudinal measurements with the bibliographical intrigues of his posthumous publication, but one must admit to the temptation.

It is known from the list of errata that the change of Hearne's direction was intentional, not the result of some accident, as in a forme of pages of type being dropped and broken or scattered across the printer's floor and then reset, or of the type's being otherwise deranged or damaged in the course of the print run. At best, even without a list of errata, this would have made an unlikely explanation in this case because two such formes would have had to meet the same accident. In the letterpress printing of a quarto, the first and second pages of the book were imposed in different formes pages $I, 4,5$, and 8 in the outer, and pages $2,3,6$, and 7 in the inner. It is known from the signature ' $\mathrm{Dd}^{\prime}$ at the bottom of page $20 \mathrm{I}$ in all copies of the first edition examined (though not in Hurtig's facsimile reprint) that 20I, the page bearing the catchword, was the first page of the twenty-sixth quarto gathering of text /thirty-first quarto gathering if preliminary matter is included), ${ }^{6 \mathrm{I}}$ and part of that gathering's outer forme. Thus, page 202 was the second page of the same gathering but part of its inner forme. Both formes would have had to meet the same fate. Then, if, contrary to the weight of evidence offered by eighty-three different copies, one can - and one must $^{62}$ - still entertain the possibility that the Hurtig reprint was made from a copy of the first edition late in the impression in which the type was changed from 'North' to 'South,' one is still left with the question: what was the authority for such a change if not the author himself, dead twenty-five months? A Bishop Douglas? A William Wales? Thomas Pennant, who also died in I792? Yet all these men would surely have had access to the words of the Stowe Ms, the Grenville Ms, or the copy in the possession of the Hudson's Bay Company from which the Grenville Ms claims to have been made. As has been seen, these copies give 'West $\&$ North' as the direction.

Like them, another reasonable candidate would seem to be someone involved intimately in the printing process. Might it simply have been a disinterested printer who could have arrived at the decision to introduce a correction after consulting the dotted line on the map of Hearne's route as published in the first edition, which leads predominantly south and slightly south west, not north west (Fig. I)? J. Tuzo Wilson was the first to note so much difference 
between manuscript $\left({ }^{\prime} \mathrm{M}^{\prime}\right)$ and published $\left({ }^{\prime} \mathrm{P}\right)$ versions of the map as to warrant distinct classifications for the unpublished ones. Glover did not serve his readers well at all by ignoring Wilson's remark that ' $t$ ] he $P$ versions are garbled, fanciful and much inferior to any of the $M$ versions. ${ }^{163}$ In the case of Hearne's route around Point Lake, however, the original map (Fig. 6 ) $^{64}$ also appears at odds with the direction given in the field notes. Its dark (green) line leads incontestably in a south-south-westerly direction, along the east side of 'Pointe Lake,' and then south-westerly until it bisects Hearne's representation of the tree-line - a feature of his map, denoted by a line and punctuated by tiny drawings of conifers, that was not reproduced either in his book's two editions or in the earlier published versions of his map. ${ }^{65}$ As well, however, this drawing of the route, if it does not align with the 'West $\&$ North' of the field notes, appears to conform to the published narrative's account of Hearne's return to trees: '. . . by the side of Point Lake. After three days journey, which only consisted of about eighteen miles, we came to a few small scrubby woods, which were the first that we had seen from the twenty-fifth of May, except those we had perceived at the Copper-mine River.'

While it does not lie within the scope of this study to argue which was or was not Hearne's route on 8 September $177 \mathrm{I}$, it is appropriate to remark that this variant, or erratum, is a substantive one. A reworking of the route under the assumption of north west as the correct direction gives rise, as Peake has argued, to the defensible thesis that the lake known today as Point Lake (Franklin's Point Lake) was not Hearne's, that Hearne's lake is more likely today's Courageous or another more in the vicinity of Lac de Gras, farther (south) up the Coppermine River. If he had with him during his own explorations more than a copy of Hearne's map, would Franklin have hauled a heavy quarto first edition five decades after Hearne had seen the Coppermine River, or would the naval captain have had with him the Dublin octavo, which as has been seen gives 'South West' as the direction? ${ }^{66}$ Meanwhile in this century, because neither Tyrrell nor Glover noted the variant when preparing their editions, it is arguably no more than chance that the route has been taken as south west. The Hurtig 'facsimile' reprint will serve only to confirm as much. 


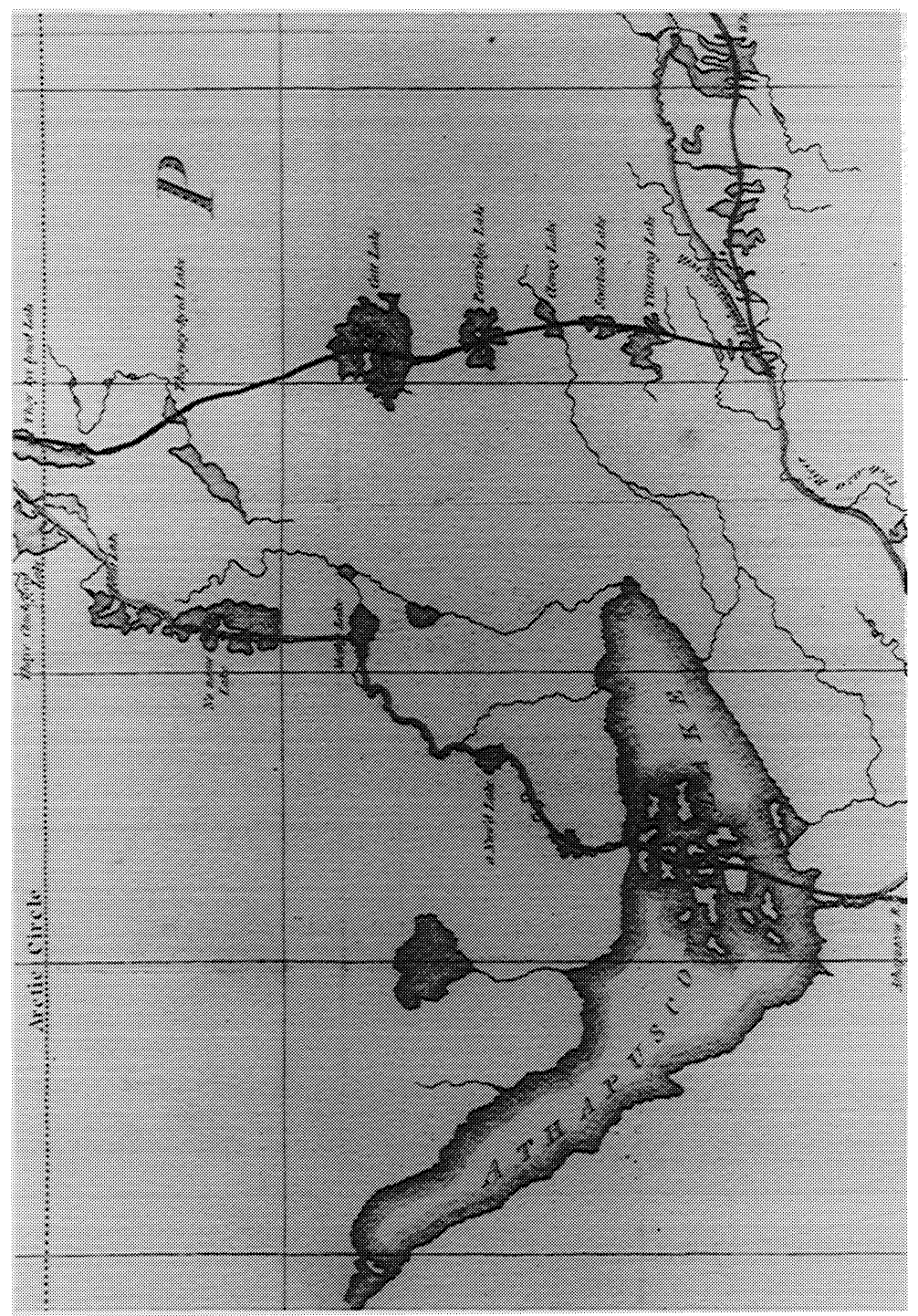

FIG. I Detail from: A Map exhibiting $M^{R}$ HEARNE'S TRACKS in his two Journies for the discovery of the COPPER MINE RIVER, in the Years 1770,1771 and 1772 ; under the direction of the HUDSON'S BAY COMPANY (London, 1795, opp. title page). 


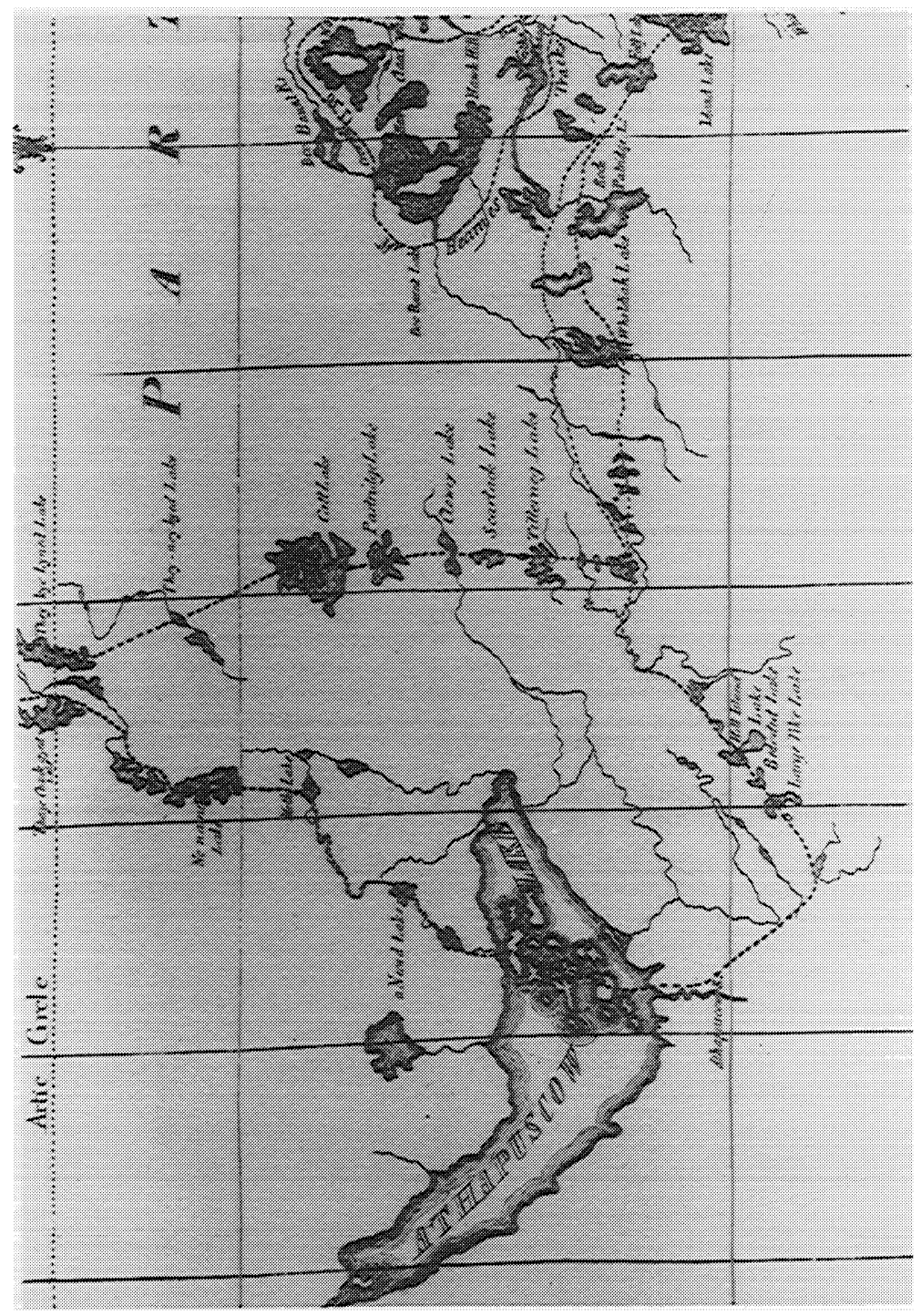

FIG. 2 Detail from: A MAP exhibiting $M^{R}$ HEARNES TrACKs in his two Journies for the discovery of the COPPER MINE RIVER, in the Years 1770, I77I and 1772; under the direction of the HUDSON'S BAY COMPANY (London, I796, opp. title page). 
A

J O U R N E Y

$\frac{1006}{20}$

Prince of Wales's Fort, in Hudfon's Bay, ro

THE NORTEERN OCEAN.

$v * x+2 \times x \times 2 \times x$

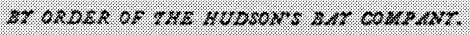

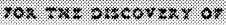

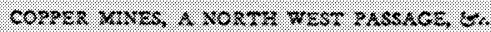

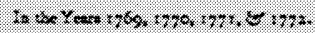

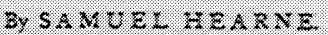

$$
20 \times 0 \times 2
$$

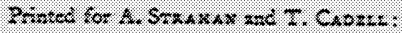

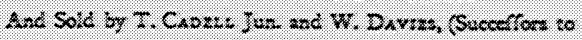

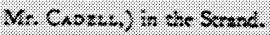

2795

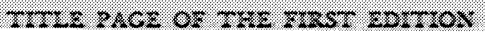

Fig. 3 'Title Page of the First Edition' (Glover, [xlv]). 
a

$$
\text { f. }
$$

Prince of Wales's Fort in Hudion's Bay,

i. 0

T R E NORTRE R N OCE AN.

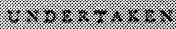

:

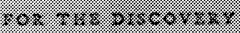

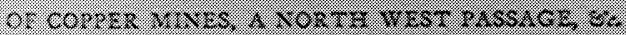

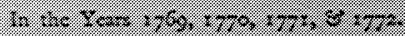

By S A M U E L A B A R N E.

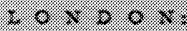

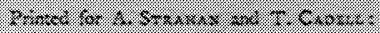

t.

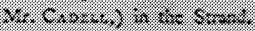

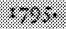

Fig. 4 Title-page from the first edition (London, 1795). 


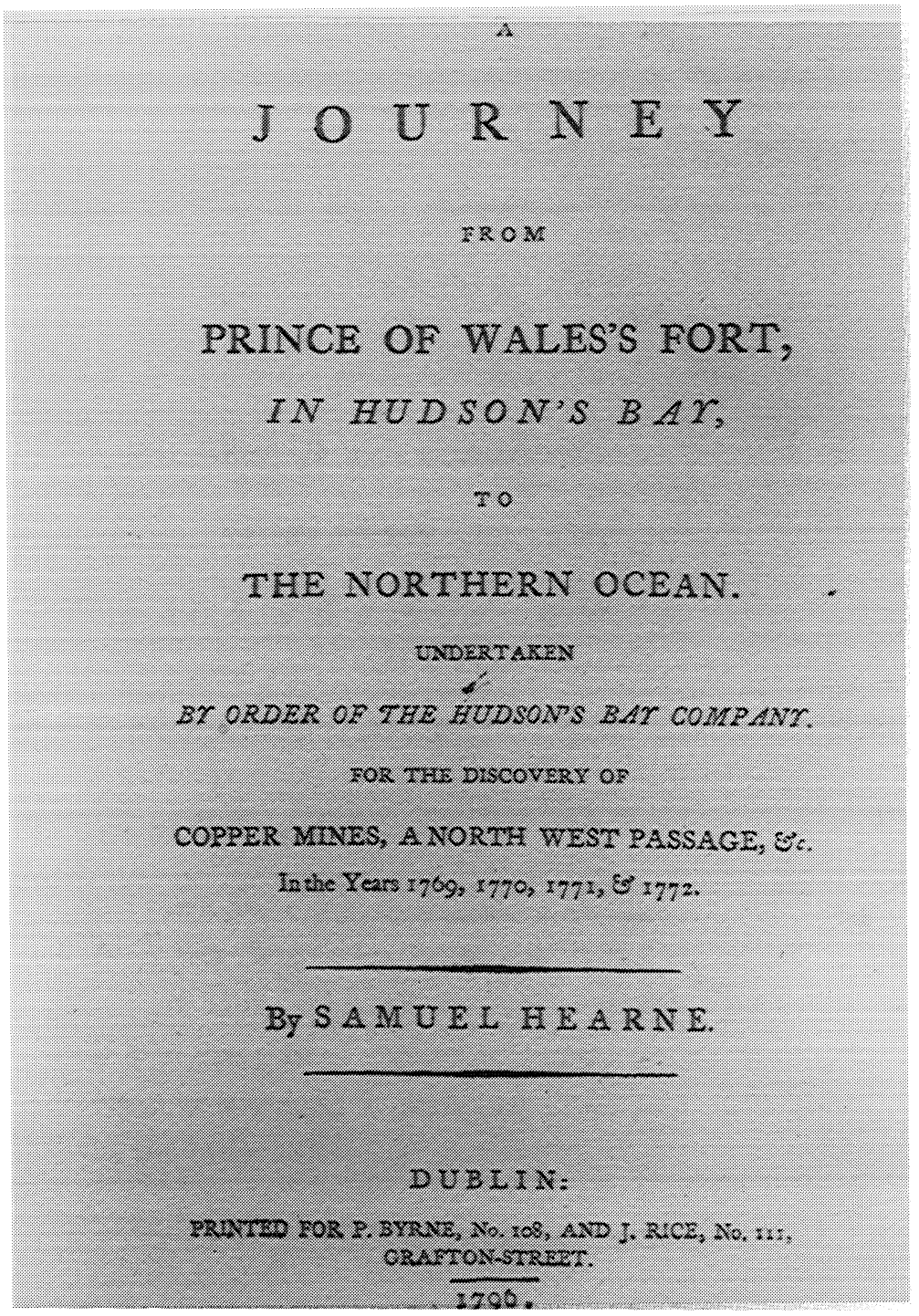

FIG. 5 Title-page from the second edition (Dublin, 1796). 


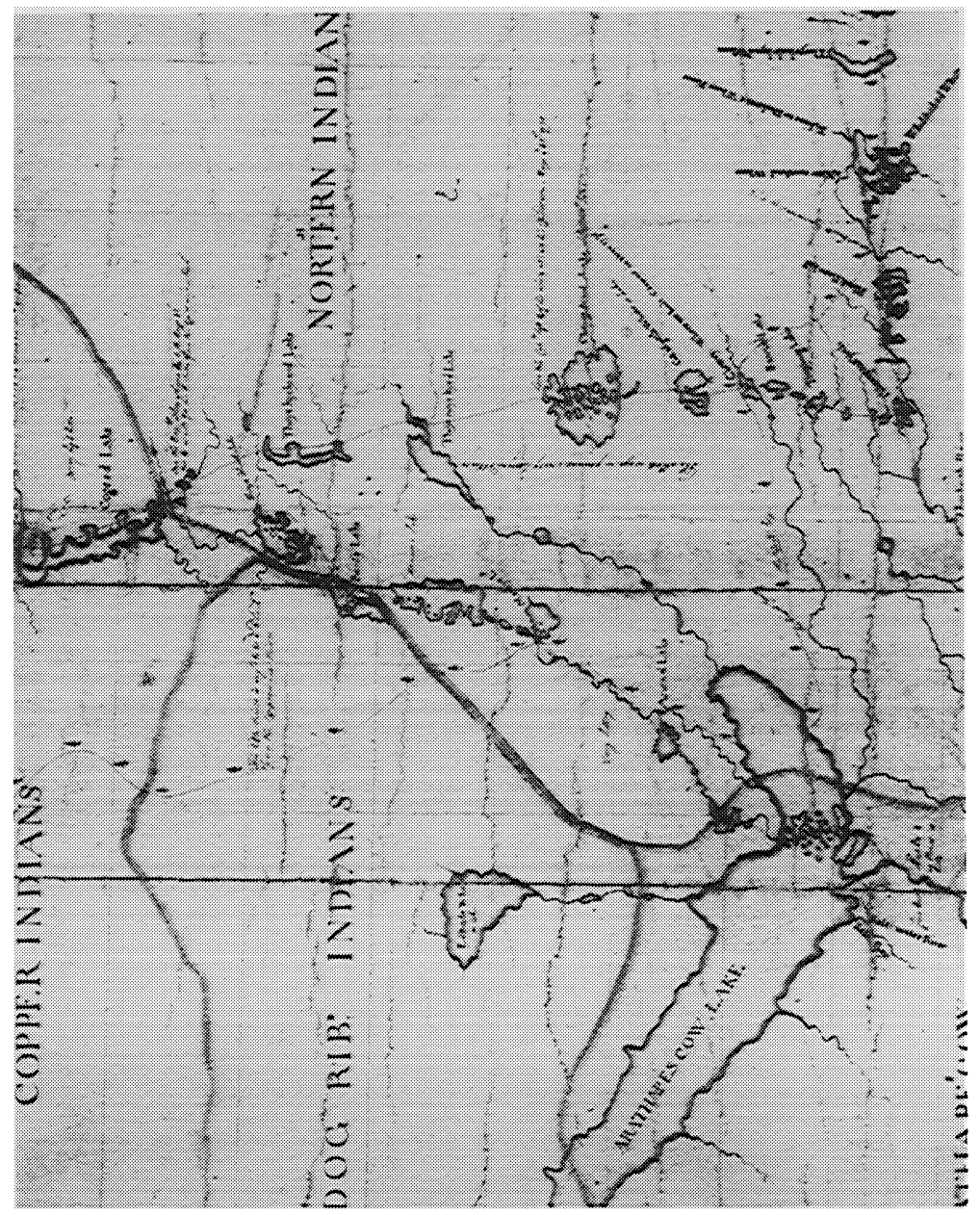

Fig. 6 Detail from: 'A Map of part of the Inland Country to the $\mathrm{N}^{r} \mathrm{~W}^{\mathrm{t}}$ of PRINCE of WALE'S [sic] Fort $\mathrm{H}^{\mathrm{s} B} \mathrm{y}$ Humbly Inscribed to the Gov' Depy Gov' ${ }^{\mathrm{nr}}$ and Committee of the Honble Huds By Compy By their Hon $^{\text {rs }}$ most obediant humble servant Sam ${ }^{1}$ Hearne, I772' (1772); Courtesy Hudson's Bay Company Archives, Provincial Archives of Manitoba; HBCA Map Collection G.2/Io (N95 ro). 
I wish to acknowledge with thanks the assistance rendered the research for this paper by Sean Peake, an avid canoeist and private scholar from Toronto; by John Charles and Jeannine Green, of the Bruce Peel Special Collections Library, The University of Alberta; by Merrill Distad, Collections Co-ordinator, The University of Alberta Libraries; by Judith Hudson Beattie, Keeper, Hudson's Bay Company Archives; by Douglas Chambers, Trinity College, University of Toronto; and by Sandra Alston, Canadiana Book Selector, University of Toronto Library, and President, The Bibliographical Society of Canada. Finally, I thank and salute the individuals and librarians at rare books and special collections libraries who responded with alacrity to my request for a survey of their own or their institutions' copy or copies of the first edition of $A$ Journey from Prince of Wales's Fort: American Antiquarian Society; Bibliothèque centrale de la ville de Montréal; Bibliothèque nationale du Québec; Boston Public Library; Bowdoin College; Brigham Young University; British Library; Brown University; Buffalo and Erie County Public Library; California State Library; Cambridge University; Columbia University; Commonwealth of Massachusetts State Library; Commonwealth of Virginia State Library and Archives; Dalhousie University; Durham Dean and Chapter Library; Emory University; Field Museum of Natural History; Florida State University; Der Göttinger Arbeitskreis e.V.; C. Stuart Houston; Hudson's Bay Company Archives; Mel Hurtig; Helen Kahn; John Carter Brown Library; Johns Hopkins University; Lehigh University; Literary and Philosophical Society of Newcastle Upon Tyne; McCord Museum of Canadian History; McGill University; Marquette University; Massachusetts Historical Society; Metropolitan Toronto Library; Michigan State University; Mills College; National Library of Canada; National Library of Ireland; National Library of Scotland; Newberry Library; New York Public Library; Oregon Historical Society; Oxford University (Christ Church Library); Peabody and Essex Museum; Public Archives of Nova Scotia; Royal Geographical Society of Australasia; St. John's College, Cambridge; Scott Polar Research Institute; Syracuse University; Trinity College, Dublin; Trinity College, Hartford, Connecticut; Universiteitsbiliotheek Amsterdam; University of Alberta; University of British Columbia; University of California at San Diego; University of Chicago; University of Glasgow; University of Illinois (Urbana); University of Manitoba; University of New Brunswick; University of Oregon; University of Pennsylvania; University of Regina; University of St. Andrews; University of Saskatchewan; University of South Africa; University of Texas at Austin; University of Toronto; University of Virginia; University of Western Ontario; and William Jewell College.

NOTES

I Samuel Hearne, A Journey from Prince of Wales's Fort, in Hudson's Bay, to the Northern Ocean. Undertaken by Order of the Hudson's Bay Company, for the Discovery of Copper Mines, a North West Passage, ex. in the Years I769, I770, I771, \& 1772 (London: For A. Strahan and T. Cadell, 1795).

2 Samuel Hearne, A Journey from Prince of Wales's Fort in Hudson's Bay to the Northern Ocean 1769. I770. I77I. I772, ed., and with an introduction, by 
Richard Glover (Toronto: Macmillan of Canada, 1958).

3 Stowe mss vol. 307, ff. 66-89.

4 MG 2I, Stowe MS 307 FF-67-89 I79I, 6I pp.

5 Dropmore Papers, Grenville Ms. ADD. $59237,47 \mathrm{ff}$. The Grenville manuscript is mentioned in R.A.H. Smith, 'The Dropmore Papers (Add. Mss. 58855-59494),' The British Library Journal, vol. 7, no. I (198I): 75-87. It is unknown if this copy precedes or succeeds that in the Stowe Mss; the evidence of the water-mark is inconclusive.

6 Andrew Graham, Andrew Graham's Observations on Hudson's Bay 1767I79I, ed. by Glyndwr Williams, introd. by R. Glover, Publications of the Hudson's Bay Record Society, vol. 27 (London: Hudson's Bay Record Society, 1969), 196-200.

7 See I.S. MacLaren, 'Exploring Canadian Literature: Samuel Hearne and the Inuit Girl,' in Probing Canadian Culture, ed. Peter Easingwood, Konrad Gross, and Wolfgang Klooß; Beitrag zur Kanadistik: Band I, Schriftenreihe der Gesellschaft für Kanada-Studien (Augsburg: AvVerlag, 1991), 87-106.

8 'Massacre of Esquimaux by the Indians,' The Mirror of Literature, Amusement, and Instruction, 2 (6 Dec. 1823): 466-68.

9 [A. Coleson], Miss Coleson's Narrative of her Captivity among the Sioux Indians!, The Garland Library of Narratives of North American Indian Captivities, vol. 79 (New York: Garland, 1977), 24-6; facs. rpt. of the first edition (Philadelphia: Barclay \& Co., I 864). For this last reference, I am grateful to my colleague, Robin McGrath.

Io Glover, ed., A Journey from Prince of Wales's Fort, Ioon.

I I Peter C. Newman, The Company of Adventurers, vol. I (Markham, Ont: Penguin, 1986 [orig. publ. 1985]), 352-54; M.J. Brand, 'Samuel Hearne and the Massacre at Bloody Falls [sic],' Polar Record, 28, no. I66 (July I992): 229-32; I.S. MacLaren, "Samuel Hearne and the Landscapes of Discovery," Canadian Literature, no. 103 (Winter 1984): 27-40; and Terry Goldie, Fear and Temptation: The Image of the Indigene in Canadian, Australian, and New Zealand Literatures (Kingston, Montréal, London: McGill-Queen's University Press, I989), 43-7.

12 'Mr. Hearne's Narrative,' Stowe Ms, f76v; NAC transcription, 27, 26; rpt. in I.S. MacLaren, 'Samuel Hearne's Accounts of the Massacre at Bloody Fall, 17 July I771,' Ariel: A Review of International English Literature, vol. 22, no. I (Jan. I99I): 30; 'Hearne's Journal 1770-72,' Grenville Ms, f2 Iv.

I 3 'Mr. Hearne's Narrative,' Stowe Ms, f77r; NAC transcription, 28; rpt. in MacLaren, 'Samuel Hearne's Accounts': 31 ; 'Hearne's Journal I770-72,' Grenville Ms, f $22 v$.

I4 'Mr. Hearne's Narrative,' Stowe Ms, f76v; NAC transcription, 27; rpt. in MacLaren, 'Samuel Hearne's Accounts': 30; 'Hearne's Journal I770-72,' Grenville Ms, f 2 Iv.

The Grenville ms differs slightly only in the punctuation. It reads as follows: '... the Indians crept under some of the rocks within roo yards of the tent where they lay some time to watch the motions of the Esquimaux; but finding all asleep 
as they supposed by seeing nobody stir without they ran on the tent on a sudden, \& killed every soul before they had power to rise, in the whole $2 \mathrm{I}$ persons.'

15 Andrew Graham's Observations, 198-99.

16 'Mr. Hearne's Narrative,' Stowe Ms, f77r; NAC transcription, 27; rpt. in MacLaren, 'Samuel Hearne's Accounts': 31 ; 'Hearne's Journal 1770-72,' Grenville Ms, f22r.

17 Glover, ed., A Journey from Prince of Wales's Fort, xxxvii-xliii.

I 8 Leslie H. Neatby, 'Introduction to the New Edition,' in Hearne, $A$ Journey from Prince of Wales's Fort in Hudson's Bay to the Northern Ocean. Undertaken by Order of the Hudson's Bay Company for the Discovery of Copper Mines, a North West Passage, $₫$ c. In the Years 1769, 1770, 1771, $₫ 1772$; facs. rpt. of the first edition (Edmonton: M.G. Hurtig, I97I), xxiii-xxv.

I9 Samuel Hearne, A Journey from Prince of Wales's Fort (1795), iii-iv.

20 MacLaren, 'Samuel Hearne's Accounts': 36-9.

2I See the salutary and timely flaying administered Columbian editors by David Henige, In Search of Columbus: The Sources of the First Voyage (Tucson, Ariz.: University of Arizona Press, 1991).

22 Brand, 'Samuel Hearne and the Massacre at Bloody Falls [sic]': $23 \mathrm{I}$.

23 Richard Glover, 'A Note on John Richardson's "Digression Concerning Hearne's Route",' Canadian Historical Review, 32 (I95 I): 252-63; Glover, ed., A lourney from Prince of Wales's Fort, $\mathbf{x x x}$-xxxi.

24 James Cook [John Douglas, ed.], A Voyage to the Pacific Ocean. Undertaken by the Command of His Majesty, for making Discoveries in the Northern Hemisphere . . , 3 vols. and Atlas (London: For G. Nicol and T. Cadell, 1784).

25 Ibid., I: xlvii-xlix.

26 This discrepancy is discussed in MacLaren, 'Exploration/Travel Literature and the Evolution of the Author,' International Journal of Canadian Studies/Revue internationale d'études canadiennes, no. 5 (Spring/Printemps, 1992): 39-68.

27 Hearne, A Journey from Prince of Wales's Fort (1795), 155; Glover, ed., A Journey from Prince of Wales's Fort, roo.

28 Hearne, A Journey from Prince of Wales's Fort (1795), I 64, 166; Glover, ed., $A$ Journey from Prince of Wales's Fort, 106, 108.

29 The source of this report is Captain John Franklin's midshipman George Back, who travelled in $182 \mathrm{I}$ during Franklin's first overland expedition with a man Annoethai-yazzeh - who had also accompanied Hearne. See C. Stuart Houston, ed., To the Arctic by Canoe I819-1821: the Journal and Paintings of Robert Hood, Midshipman with Franklin (Montréal and London: McGill-Queen's University Press, 1974l, I33n; and MacLaren, 'Samuel Hearne's Accounts': 46-7. Houston's edition of Back's journal from this expedition, including the midshipman's doubt concerning Hearne's presence at the massacre, is forthcoming from McGill-Queen's University Press as Arctic Artist: The Journal and Paintings of George Back, Midshipman with Franklin I819-1822.

30 Glyndwr Williams, 'Highlights of the First 200 Years of the Hudson's Bay Company,' The Beaver, 301 (Autumn 1970): 25; and Glyndwr Williams, 'The Puzzle of Anthony Henday's Journal, 1754-55,' The Beaver, 309 (Autumn I978): 4 I. 
3 I Sean Peake, 'Hot on a cold trail - rewriting Samuel Hearne's track: part one,' 1991, unpubl. typescript.

32 Samuel Hearne, A Journey from Prince of Wales's Fort $|\mathrm{1795}|$; and facs. rpt. of the first edition, Biblioteca Australiana \# 25, (Amsterdam: N. Israel; New York: Da Capo, 1968|, 202.

33 Ibid., [xx].

34 'Mr. Hearne's Narrative,' Stowe ms, f8or; NAC transcription, 37.

35 'Hearne's Journal $1770-72$,' Grenville Ms, f3or.

36 The other four errata have to do with typos and the faulty inclusion of two pronouns - 'he' and ' $w e^{\prime}$ - where only the first is required. One of the typos is, however, not uninteresting, since it has to do with altering the spelling of Hearne's name for Great Slave Lake: 'I I I - I2, for Athapusco read Athapuscow.' It is worth noting in this connection as well that neither of these spellings corresponds to the rendering given on Hearne's original map: 'Arathapescow Lake' (Fig. 6).

37 Samuel Hearne, A Journey from Prince of Wales's Fort, in Hudson's Bay, to the Northern Ocean. Undertaken by Order of the Hudson's Bay Company. For the Discovery of Copper Mines, a North West Passage, $₫ c$. in the Years 1769, $1770,1771, \& 1772$ (1795) (Ottawa: Canadian Institute for Historical Microreproductions, 1982), 6 microfiches, no. 35434.

38 In the case of only a dozen copies was a check made to see if any of the other errata were corrected in pencil; occasionally, as in the copy held by the National Library of Canada and microfilmed by the сгнм, all the errata are corrected. In the NLC/CiHM copy as well, a zealous reader has extended the list to a sixth erratum and also made the correction in the text: ' $125-4$, for is read are' $[[\mathrm{xx}]$; to conform to the format of the printed errata, the words not underlined should have been, and vice versa).

39 J.B. Tyrrell, ed., A Journey from Prince of Wales's Fort in Hudson's Bay to the Northern Ocean in the Years $1769,1770,1771$, and 1772. By Samuel Hearne, Publications of the Champlain Society, vol. vi /Toronto: The Champlain Society, I9II), 23.

40 Ibid., 218.

4 I Ibid., I I2, I2 I, I29, 146.

42 Hearne: a Journey from Prince of Wales's Fort in Hudson's Bay to the Northern Ocean. Originally published as Champlain Society Publication vI (I9I I), facs rpt. (New York: Greenwood, I968), 2 I 8.

43 Glover, ed., A Journey from Prince of Wales's Fort, $13 \mathrm{I}$.

44 Ibid., 43, 50, 56, 71.

45 Samuel Hearne, Journey from Prince of Wales's Fort, in Hudson's Bay, to the Northern Ocean. Undertaken by Order of the Hudson's Bay Company. For the Discovery of Copper Mines, a North West Passage, $₫$ c. in the Years 1769 , 1770, 1771, \& 1772 (Dublin: For P. Byrne and J. Rice, 1796), 201; and rpt. (Ottawa: Canadian Institute for Historical Microreproductions, 1982), 6 microfiches, no. 40172.

46 Glover, ed., A Journey from Prince of Wales's Fort, [lv]. 
47 Ibid., [i].

48 Ibid., [xlv].

49 Landries van 't Prins van Wallis Fort aan Hudsons Baai, naar den NoorderOceaan. Ondernomen op bevel van de Maatschappij der Hudsons Baai, ter Ontdekkinge van Koper-Mijnen, een Noord-Westen Doortogt, enz. in de Jaren I769, I770, I77I en I772. Door Samuel Hearne. Uit het Engelsch vertaald met Annmerkingen van Johann Reinhold Forster, 2 vols. (The Hague: For J.C. Leeuwnstijn, 1798), II: 17; rpt. (Ottawa: Canadian Institute for Historical Microreproductions, 1982), 3 microfiches (vol. I), no. 18140; 4 microfiches (vol. II), no. I8I4I.

50 Samuel Hearnes Resa til Norra Americas ishaf, samt en Obekant Engelsmans Resor Bland Canadas Wildar, utgifne af Le Long: soamte Edvard Umfrevilles Beskrifning om Hudsons Baye och des Tilgroansande Wildar (Stockholm: For Johan Pfeiffer, 1798), 124; rpt. (Ottawa: Canadian Institute for Historical Microreproductions, 1982), 5 microfiches, no. I77 I I.

51 Voyage de Samuel Hearne, du Fort du Prince de Galles dans la Baie de Hudson, a [sic] l'Océan Nord, Entrepris par Ordre de la Compagnie de la Baie de Hudson, dans les Années $1769,1770,1771$, et 1772, et exécuté par Terre, pour la Découverte d'un Passage au Nord-Ouest. Traduit de l'Anglais, et Accompagné de Cartes et de Planches, 2 vols (Paris: Imprimerie de Patris, An vir [1799]), I:I3 I. (A microfiche reprint was not located in the сгнм files.) Despite the fact that The National Union Catalogue Pre-1956 Imprints contains two separate entries for the French translation, one dated 1798 and apparently published by 'de Patrès,' and the other dated 1799 and published by 'de Patris,' there was only the one edition, that of 1799 . Confirmation of this was obtained from Richard J. Wolfe, Curator of Rare Books and Manuscripts, the Joseph Garland Librarian of the Boston Medical Library. The Francis A. Countway Library of Medicine, a division of the Boston Medical Library, is listed in the NUC (vol. 237, p. 274) as the only repository of the edition of 1798 , but an examination of that copy indicates that the title-pages of the two volumes match those of the edition of 1799 . Most likely, then, the discrepancy can be accounted for by errors made in converting the post-French-Revolution date, as shown on the title-pages, of 'An VII,' and in listing the name of the publisher.

52 Journey from Fort Prince of Wales, in Hudson's Bay, to the Northern Ocean, for the Discovery of Copper Mines and a North-West Passage, Performed between the Years 1769 and 1772 by Mr. Samuel Hearne (Philadelphia: Joseph and James Crukshank, 1802), 73; rpt. (Ottawa: Canadian Institute for Historical Microreproductions, 1982), 2 microfiches, no. 18327.

53 Samuel Hearne's Reise von dem Prinz von Wallis-fort and der Hudsons-Bay bis zu dem Eismeere, in den Jahren 1769 bis 1772 . Aus dem Englischen übersetzt. Mit Anmerkungen von Johann Reinhold Forster, Professor der Naturgeschichte und Mineralogie in Halle, mit Glied der R. Dr. Akademie der Wissenschaften ec., Magazin von Merkwürdigen neuen Reisebeschreibungen, vol. I4 (Berlin: In der Vossichen Buchhandlung, 1797), r86; rpt. (Ottawa: Canadian Institute for Historical Microreproductions, I982), 4 micro- 
fiches, no. 177 IO. The ciнm microfiches of this translation are illegible in places because of extensive show through of ink from one page onto the facing recto or verso. I acknowledge with gratitude the assistance provided by Brian Young, Reference Librarian, British Columbia Archives and Records Services, Victoria, who examined the copy from which the microfiches were made, and who furnished legible copies of the passage in question.

54 Samuel Hearne Abenteuer im arktischen Kanada Die Suche nach der Nordwest-Passage 1769-1772 Herausgegeben und Eingeführt von Volker Matthies (Tübingen: Edition Erdmann Verlags-GmbH, 198I), 197.

55 See note 18 , above.

56 See note 32 , above.

57 Author's telephone communication with Mel Hurtig, ro September 1992.

58 Letter, N.J.C. Ingleton, Charles E. Tuttle, Inc., to the author, I 3 November 1992. 59 Capt. John Franklin, Narrative of a Journey to the Shores of the Polar Sea, in the Years $1819,20,21$, and 22 (London: John Murray, 1823); and Sir John Richardson, 'Digression concerning Hearne's route,' in Narrative of the Arctic Land Expedition to the Mouth of the Great Fish River, and along the Shores of the Arctic Ocean, in the Years I833, 1834, and I835 by Captain George Back, R.N. Commander of the Expedition (London: John Murray, 1836), I44-55.

60 Tyrrell, ed., A Journey from Prince of Wales's Fort, passim; Charles Camsell, An Exploration of the Tazin and Taltson Rivers North West Territories, Geological Survey of Canada Memoir 84 (Ottawa: Geological Survey of Canada, I9I6); Guy Blanchet, 'Thelewey-aza-yeth,' The Beaver, 280 (Sept. 1949): 8-I I; J. Tuzo Wilson, 'New Light on Hearne,' The Beaver, 280 (June 1949): 14-18; William Fuller, 'Hearne's Thelewey-aza-yeth: Another Interpretation,' MuskOx, 27 (1980): 67-74; Eric Morse, 'Modern maps throw New Light on Samuel Hearne's Route,' Cartographica, vol. 18, no. 4 (1981): 23-35; and Sean Peake, see above, note $3 \mathrm{I}$.

6I I acknowledge with thanks Bruce Whiteman's correction of my preliminary error in collation. The collation of the first edition is as follows: $\pi^{2} A-E^{4} 2 B-3 M^{4} 3 N^{2}$.

62 One ignores at one's peril the admonition given by James Thorpe: 'No matter how many copies are collated in search of variants, there is always the possibility of another copy lurking in yet one more collection with a previously unknown variant' (Principles of Textual Criticism [San Marino, Cal: The Huntington Library, 1972], 75).

63 Wilson, 'New Light': 15.

64 This map is also reproduced in Wilson,'New Light': I6-17; and Richard I. Ruggles, A Country so Interesting: The Hudson's Bay Company and Two Centuries of Mapping 1670-1870 (Montréal: McGill-Queen's University Press, I991), I33.

65 James Cook [John Douglas, ed.], A Voyage to the Pacific Ocean . . . ; and Thomas Pennant, Supplement to the Arctic Zoology (London: H. Hughs, 1787). Both of these maps are reproduced, somewhat altered, in Tyrrell, ed., following p. 18. The first complete edition of the latter was: Arctic Zoology, 2 vols. in 3 
(London: R. Faulder, 1792).

66 Preparing Franklin's journals for publication, Rick Davis confirms that it is unknown which edition Franklin and his officers took. Letter, Rick Davis to the author, 26 November 1992. 
